\title{
Polymorphism of TLR2 in bank vole populations in North Eastern Poland is not associated with Borrelia afzelii infection prevalence
}

\author{
Ewa Tarnowska $^{1}$ (D) $\cdot$ Magdalena Niedziałkowska $^{1} \cdot$ Joanna Stojak $^{1} \cdot$ Bogumiła Jędrzejewska $^{1}$
}

Received: 11 October 2019 / Accepted: 17 June 2020 / Published online: 30 June 2020

(C) The Author(s) 2020

\begin{abstract}
Polymorphism in innate immune genes in host populations can structure spatial variation in the prevalence of infectious diseases. In Europe, Borrelia afzelii is an important tick-borne pathogen of small mammals including the bank voles (Myodes glareolus). The Toll-like receptor 2 (TLR2) is an innate immune receptor that is important for detecting Borrelia burgdorferi sensu lato pathogens. The TLR2 gene is polymorphic in bank vole populations and is classified into four distinct clusters: $\mathrm{C} 1, \mathrm{C} 2, \mathrm{C} 3$, and $\mathrm{C} 4$. The $\mathrm{C} 2$ and $\mathrm{C} 4$ clusters versus the $\mathrm{C} 1$ and $\mathrm{C} 3$ clusters are associated with lower versus higher infection prevalence, respectively. We detected three TLR2 clusters in 487 bank voles from 30 populations in NE Poland: $84.2 \%$ of the obtained sequences belonged to the $\mathrm{C} 1$ variant, $7.2 \%$ to $\mathrm{C} 2$, and $8.6 \%$ to $\mathrm{C} 3$. However, no clear spatial structure of TLR2 clusters among the populations was detected. B. afzelii infection prevalence across all studied individuals was $12.1 \%$ and varied from 0 to $37.5 \%$ among populations. There were no significant differences in $B$. afzelii prevalence among voles carrying alleles of different TLR2 clusters, or between individuals belonging to two mtDNA lineages. Most infected individuals were adults, and males were infected more often than females. There was no significant relationship between the prevalence of TLR2 clusters in the vole populations and climatic and environmental factors within the study area. We therefore could not confirm an adaptive role of the TLR2 C2 alleles in reducing B. afzelii infection prevalence in bank voles.
\end{abstract}

Keywords Clethrionomys glareolus $\cdot$ Environmental factors $\cdot$ Lyme disease $\cdot$ mtDNA $\cdot$ Protein

\section{Introduction}

Lyme disease (LD) is the most common tick-borne disease in the human population across Europe, Asia and North America (Kilpatrick et al. 2017; Estrada-Peña et al. 2018). The causative agents of LD are some species of the bacterial Borrelia burgdorferi sensu lato complex (Hanincová et al. 2006; Franke et al. 2013; Hofmeester et al. 2016; Estrada-Peña et al. 2018). Members of this complex can infect various

Communicated by: Jeremy Herman

Electronic supplementary material The online version of this article (https://doi.org/10.1007/s13364-020-00518-7) contains supplementary material, which is available to authorized users.

Ewa Tarnowska

etarnowska@ibs.bialowieza.pl

1 Mammal Research Institute, Polish Academy of Sciences, ul. Stoczek 1, 17-230 Białowieża, Poland vertebrate species, including humans (Coipan et al. 2018). However, individual Borrelia species are specialized on different vertebrate hosts (Kurtenbach et al. 2002; Piesman and Gern 2004). For example, Borrelia garini and B. valaisiana are specific to birds (Hanincová et al. 2003b) while B. afzelii is specific to small mammals, including rodents, which are the main reservoir and source of $B$. afzelii (Hanincová et al. 2003a; Hofmeester et al. 2016).

B. afzelii is the most common cause of LD in humans in central Europe (Estrada-Peña et al. 2018). This bacterium is transmitted via infected ticks, with the most important tick vector for B. afzelii in Europe being the castor bean tick (Ixodes ricinus) (van Duijvendijk et al. 2015; Hofmeester et al. 2016; Strnad et al. 2017). One of the most important rodent hosts for B. afzelii in Europe is the bank vole (Myodes glareolus) (Tälleklint et al. 1993; Kurtenbach et al. 1995; Humair et al. 1999). The spread of Borrelia in tick populations is determined by the specific infectivity of voles, seasonality, the degree of acquired resistance to ticks and the age composition of the vole population (Kurtenbach et al. 1995; Tälleklint et al. 1993). 
Toll-like receptors (TLRs) are part of the vertebrates' antimicrobial innate immunity, which recognize a variety of microbial products such as peptidoglycan, lipoproteins, lipopolysaccharides, lipoteichoic acids, bacterial flagellin and CpG DNA (Hirschfeld et al. 1999; Medzhitov 2001; Wooten et al. 2002). Their presence is the first signal of infection for the organism. Such recognition of microbial products by TLRs leads to functional maturation of dendritic cells and to initiation of antigen-specific adaptive immune responses (Medzhitov 2001). The main function of TLRs is to recognize pathogens, thus TLRs evolved under parasite-driven selection (Kloch et al. 2018). This natural selection has shaped the genetic diversity of host populations.

Toll-like receptor 2 (TLR2) plays a key role in the response to Borrelia infection (Hirschfeld et al. 1999; Wooten et al. 2002; Garantziotis et al. 2008). TLR2 is specific to peptidoglycan and lipoproteins and cooperates with TLR1 and TLR6 in the recognition of distinct sets of ligands (Hirschfeld et al. 1999, Medzhitov 2001). The interaction between lipoproteins and TLR2 activates cells involved in innate defence, prompting infiltration of professional phagocytes, phagocytosis or killing of spirochetes (Wooten et al. 2002).

Recent studies of the relationships between B. afzelii prevalence and bank vole populations have investigated parasitemediated selection, and the role of TLR2 in shaping infection prevalence within and across European populations of voles (e.g. Tschirren et al. 2013; Tschirren 2015; Morger et al. 2015; Gomez-Chamorro et al. 2019a). Population genetic analysis of the TLR2 genes of the bank vole may give insights into parasite-mediated selection, and could elucidate the role of parasites in creating and maintaining diversity of immune genes within and among host populations (e.g. Haldane 1949; Tschirren et al. 2011). It has been suggested that $68 \%$ of the TLR2 sequence evolved under strong purifying selection, $32 \%$ evolved neutrally, and $0.5-0.6 \%$ of all sites (3-5 amino acids) were shaped by positive selection (Tschirren et al. 2011).

In bank voles, four TLR 2 clusters: $\mathrm{C} 1, \mathrm{C} 2, \mathrm{C} 3, \mathrm{C} 4$ (groups of similar haplotypes, which differ from each other by single nucleotide polymorphisms) are associated with variation in infection prevalence of B. afzelii (Tschirren et al. 2013; Morger et al. 2015). Field studies found that individuals with the $\mathrm{C} 2 \mathrm{C} 2, \mathrm{C} 1 \mathrm{C} 2$ and $\mathrm{C} 1 \mathrm{C} 1$ genotypes had low (approximately $15 \%)$, intermediate $(30 \%)$ and high $(50 \%)$ prevalence of infection with B. afzelii (Tschirren et al. 2013; Tschirren 2015). This led the authors (Tschirren et al. 2013) to suggest that the $\mathrm{C} 2$ allele provides resistance to $B$. afzelii infection in bank voles whereas the $\mathrm{C} 1$ allele makes bank voles more susceptible to $B$. afzelii infection.

Haplotypes belonging to the TLR2 ${ }_{C 4}$ cluster might increase resistance to $B$. afzelii infection in bank voles in a similar manner to TLR2 ${ }_{C 2}$. There is no apparent association between TLR2 ${ }_{C 3}$ haplotypes and Borrelia infection (Cornetti et al. 2018). However, a recent study by Gomez-Chamorro et al. (2019a), who experimentally infected bank voles carrying different TLR2 variants $(\mathrm{C} 1, \mathrm{C} 2$ and $\mathrm{C} 3)$ with Borrelia afzelii, showed no differences in the prevalence of $B$. afzelii infection among bank voles carrying alleles from different TLR2 clusters. To date, several hypotheses explaining the observed TLR2 genetic structure among populations have been proposed, concerning natural selection and the environment. For example, co-occurrence of three TLR2 clusters within the same population might reflect selection promoting polymorphism (Morger et al. 2015). Spatial distribution of different TLR2 clusters may be related indirectly to abiotic factors, which influence the presence of ticks and Borrelia infection prevalence. Cornetti et al. (2018) showed that in Switzerland, Borrelia infection risk was highest at low and medium elevations, and decreased with increasing elevation, which corresponded proportionally to host infection prevalence. They suggested that such small-scale spatial variation in pathogen-mediated selection shaped host gene evolution, leading to small-scale spatial variation in the immunogenetic composition of host populations. Additionally, differences in the strength of selection might lead to spatial heterogeneity in the resistance, tolerance, and life history of the host species (Cornetti et al. 2018). The Borrelia infection risk depends on the density of infected nymphs (DIN), which is shaped by both abiotic and biotic factors, and varied at a local spatial scale. There is a complicated network of factors influencing transmission of the pathogen between hosts and vectors (Ostfeld et al. 2006; Diuk-Wasser et al. 2012; Perez et al. 2016; Cayol et al. 2017). The number of nymphs depended on the density of rodents (Ostfeld et al. 2006). Host-parasite interactions also depend on the type of landscape and its fragmentation (Diuk-Wasser et al. 2012; Perez et al. 2016). The distribution and abundance of tick populations can also be shaped by both large-scale and local climatic conditions (Ostfeld et al. 2006; Kilpatrick et al. 2017). Winter survival of ticks is mostly determined by extreme temperatures and occurrence of snow cover (Karbowiak 2014; Medlock et al. 2013; Medlock and Leach 2015). Insufficient snow cover during frosts can lead to ground freezing, a consequence of which is reduction of the tick population (Medlock and Leach 2015).

European bank vole populations are classified into mitochondrial DNA (mtDNA) lineages, which are defined as temporal populations connected by a continuous line of maternal descent based on mitochondrial markers. Previous studies in Europe have shown that the TLR2 clusters are conserved among bank vole mtDNA lineages suggesting that the formation of the TLR2 clusters predated the split of the bank vole lineages and that these clusters were subsequently maintained within lineages. For this reason, we were interested in studying the association between the mtDNA lineages and the TLR2 clusters in our bank vole populations. In NE Poland, 
mainly two mtDNA lineages of the bank vole occur: the Carpathian and the Eastern (Wójcik et al. 2010; Stojak and Tarnowska 2019). These two mtDNA lineages form a contact zone that varies in width from $45 \mathrm{~km}$ in the south to $243 \mathrm{~km}$ in the north; the shape and width of this contact zone has been related to both abiotic and biotic factors (Tarnowska et al. 2016; Stojak and Tarnowska 2019). Genetic differentiation of those lineages has been shaped during isolation in different glacial refugia and postglacial recolonisation of Europe (Deffontaine et al. 2005; Kotlík et al. 2006). The spatial distribution of these two bank vole mtDNA lineages in NE Poland (Tarnowska et al. 2016) corresponds to areas of varying levels of Borrelia infection risk in Ixodes ricinus ticks (from 1 to $37 \%$ in different areas) as indicated by Sytykiewicz et al. (2012).

In our study we tested the following hypotheses: (1) frequencies of the TLR2 clusters differ between bank voles belonging to the two main mtDNA lineages in NE Poland, where the level of Borrelia infection in ticks varied spatially (Sytykiewicz et al. 2012), (2) bank voles carrying different clusters and genotypes of TLR2 differ in B. afzelii infection prevalence. The main aims of this study were to (1) estimate $B$. afzelii infection prevalence in bank voles, (2) describe the genetic diversity of TLR2 and estimate the frequencies of the three TLR2 clusters, (3) compare spatial TLR2 population structure with mtDNA lineage distribution in bank vole populations in North Eastern Poland and, finally, (4) identify which biological, climatic and environmental variables might have shaped the prevalence of $B$. afzelii infection in bank voles in NE Poland.

\section{Materials and methods}

\section{Study area and sampling}

This study was conducted in a forested area of North Eastern Poland ( $\left.52^{\circ} 21^{\prime}-54^{\circ} 20^{\prime} \mathrm{N}, 18^{\circ} 59^{\prime}-23^{\circ} 53^{\prime} \mathrm{E}\right)$, covering approximately $45,000 \mathrm{~km}^{2}$ (Fig. 1). The mean forest cover varied from $22 \%$ in the western part to $34 \%$ in the eastern part of the study area (Zielony and Kliczkowska 2012). North Eastern Poland is under the influence of two types of climate: Atlantic in the West, and continental in the East (Starkel 1991). The mean temperature in January ranges from $3.8{ }^{\circ} \mathrm{C}$ in the West to $-5.8{ }^{\circ} \mathrm{C}$ in the East, based on mean values for 1950-2000 (Hijmans et al. 2005, the World Climate database). The mean depth of snow cover varies from 7 to $14 \mathrm{~cm}$, and the e average number of days with snow cover during the calendar year varies from 44 to 80 in the western and the eastern parts of the study area, respectively (source of data: vectorized maps of mean snow fall from years 19702000 for Poland; Institute of Meteorology and Water Management - National Research Institute). According to
Sytykiewicz et al. (2012), infection prevalence of the tick Ixodes ricinus with Borrelia spirochetes varies among different tick populations in this region. However, those previously studied populations did not overlap with our study sites.

We used tissue samples from 461 bank voles from 29 populations, collected in 2006 and 2011-2013, during previous projects conducted by the Mammal Research Institute (MRI) as described in Niedziałkowska et al. (2010) and Tarnowska et al. (2016). The bank voles were live-trapped and $\sim 4-\mathrm{mm}$ samples of the end of the tails of each of the captured individuals were taken for genetic analyses. In 2014, we sampled 26 bank voles from an additional population (no. 29) according to the protocol described in Tarnowska et al. (2016); small ear fragments of each of the captured specimens were collected for the purposes of the study. In total, we analysed 487 tissue samples from bank voles from 30 localities. All analyses were conducted using this same set of 487 individuals. The number of specimens studied per population ranged from 10 to 26 , which was sufficient to reliably estimate frequencies of TLR2 genetic clusters and mtDNA lineages in each population (Morger et al. 2015; Tschirren et al. 2015; Tarnowska et al. 2016). A list of all sampling sites and numbers of collected specimens is presented in Table 1 . All samples were collected in concordance with permissions 07/2004, 15/2006, 16/2011, 43/2011, 12/2013 and 26/2014 obtained from the Local Ethical Commission in Białystok, Poland. Trapping sites were approved by the administrators of the study area.

\section{Molecular analyses}

\section{Detection of Borrelia afzelii infection}

Genomic DNA was extracted using Qiagen DNeasy Blood \& Tissue Kit (Valencia, CA, USA). DNA extraction from the $B$. afzelii control sample was carried out using the Syngen DNA Mini Kit (Syngen Biotech), according to the manufacturer's protocol. We detected infection in bank vole samples by targeting an 89-bp fragment of the flaB gene with primers specific to $B$. afzelii. We used a modified version of the qPCR protocol and primers described by Råberg (2012). PCR was carried out in $10 \mu \mathrm{L}$ volumes: $5 \mu \mathrm{L}$ HotStartTaq MasterMix (Qiagen), 0.25 pmol of each primer, $1 \mu \mathrm{L}$ of DNA, and water to a $10 \mu \mathrm{L}$ volume. The PCR profile consisted of initial incubation at $95^{\circ} \mathrm{C}$ for $15 \mathrm{~min}$ and then 45 cycles of $95{ }^{\circ} \mathrm{C}$ for $15 \mathrm{~s}, 59^{\circ} \mathrm{C}$ for $30 \mathrm{~s}$ and $72{ }^{\circ} \mathrm{C}$ for $30 \mathrm{~s}$. An additional sample of the reagent mix used to amplify the flaB gene constituted the first negative control. The second negative control contained RNAse-free water (Qiagen). For the positive controls, we used DNA isolated from inactivated B. afzelii spirochetes, kindly provided by the National Institute of Public Health (https://www.pzh.gov.pl/). The results of each PCR were 
Fig. 1 The sampling localities of 30 populations of bank vole (Myodes glareolus) in North Eastern Poland, along with the frequencies of the Carpathian and the Eastern mtDNA lineages (after Tarnowska et al. 2016)

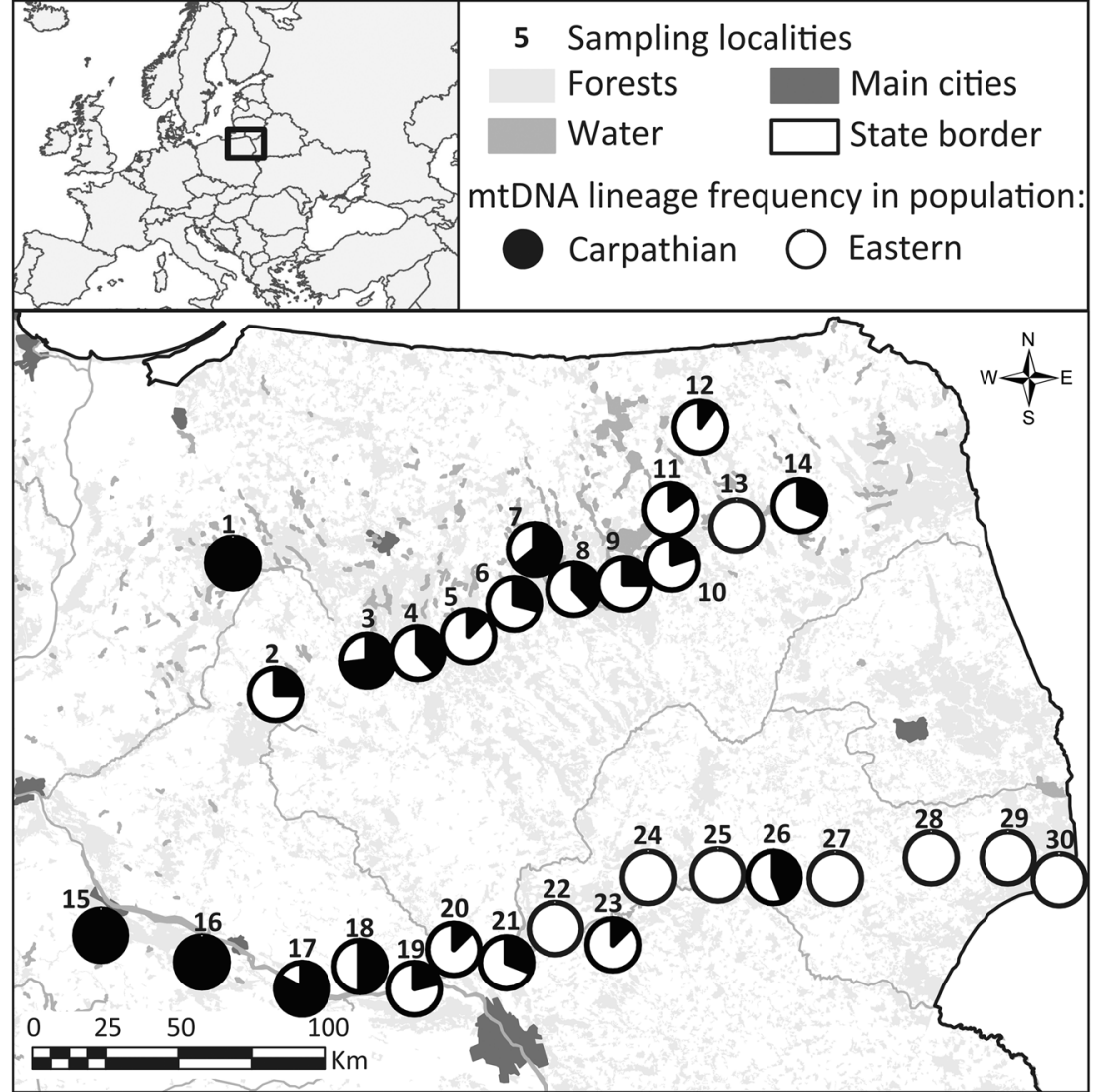

checked on $1 \%$ agarose gel. All samples were amplified twice, and only individuals with two flaB-positive results were considered as infected.

To confirm that our PCR was detecting $B$. afzelii, we amplified $25 \%$ of the flaB-positive samples and sequenced them using Fla5F primer and the Big Dye Terminator v3.1 Cycle Sequencing Kit (Applied Biosystems), according to the manufacturer's protocol. All obtained sequences were compared with sequences available in GenBank using BLAST, and thereby confirmed as belonging to the flaB gene of $B$. afzelii.

To determine the concentration of bacterial DNA, which allowed us to detect infection in voles, we prepared serial dilutions of extracted B. afzelii DNA (max concentration $2.2 \mathrm{ng} / \mu \mathrm{l}$, min concentration $2 \times 10^{-4} \mathrm{ng} / \mu \mathrm{l}$ ) and amplified the fragment of the $f l a B$ gene as described above. It was possible to detect $B$. afzelii infection in bank voles when the concentration of bacterial DNA in a sample was $2 \times 10^{-4} \mathrm{ng}$ / $\mu \mathrm{l}$ and higher.

\section{TLR2 analyses}

To determine the TLR2 genotype, we used PCR to amplify an 1173-bp fragment of the TLR2 gene. We used two sets of primers, one that were previously described by Tschirren et al. (2011) and one pair of primers designed for this study (TLR2F int: 5 ' TATTTGAG AAACTCAGCCTGTG 3' and TLR2R_int: 5' TTGTTACTAACATCCAGCACC 3'). PCRs were set in $10 \mu \mathrm{L}$ volumes. The reaction mix contained $5 \mu \mathrm{L}$ HotStartTaq MasterMix (Qiagen), 0.25 pmol of each primer and $60 \mathrm{ng}$ of DNA. The PCR profile consisted of initial incubation at $95^{\circ} \mathrm{C}$ for $15 \mathrm{~min}$ and then 37 cycles of $94^{\circ} \mathrm{C}$ for $30 \mathrm{~s}, 57^{\circ} \mathrm{C}$ for $30 \mathrm{~s}$, and $72{ }^{\circ} \mathrm{C}$ for $150 \mathrm{~s}$, with final elongation step at $72{ }^{\circ} \mathrm{C}$ for $10 \mathrm{~min}$. PCR products were purified using CleanUp kit (A\&A Biotechnology).

Next, we used MglTLR2F and TLR2F_int primers and the Big Dye Terminator (BDT) v3.1 Cycle Sequencing Kit (Applied Biosystems) to obtain TLR2 DNA sequences. The reaction mix contained $1.5 \mu \mathrm{L}$ BDT, $1.5 \mu \mathrm{L} 10 \mathrm{X}$ BDT buffer, 25 pmol primer, 10 ng of amplified and purified DNA. Sequencing was performed on ABI PRISM 3130xl sequencer (Applied Biosystems). Obtained sequences were read and checked manually in ChromasLite v2.4 (http://technelysium.com.au/) and aligned in BioEdit 7.0.5 (Hall 1999). For reference sequences, we used three haplotype sequences described and deposited in the GenBank database by Tschirren et al. (2012) (accession numbers: JN674541, JN674538 and JN674535). Haplotypes found in only one specimen were checked against the GenBank database and repeat sequenced if necessary, to avoid genotyping mistakes. 


\section{Cytochrome $b$ analyses}

MtDNA sequences of 461 individuals (from 29 populations) were taken from our previous study (Tarnowska et al. 2016). We used 424-bp fragment of the cytochrome $b$ target to determine the mitochondrial lineage of each bank vole. The cytochrome $b$ analysis of bank vole samples from one new population (population number $29 ; n=26$ bank voles) targeted the same 424bp fragment of the cytochrome $b$ gene and was conducted according to the protocol by Tarnowska et al. (2016).

Table 1 The Toll-like receptor 2 (TLR2) gene diversity of 30 bank vole populations in NE Poland. Pop population number (see Fig. 1); $N$ number of analysed individuals; $S$ number of variable sites; $h$ number of TLR2 haplotypes; $H d$ haplotype diversity; $k$ average number of nucleotide differences; $\pi$ nucleotide diversity; $A$ number of amino acid variants; $A_{p r v}$ number of private amino acid variants in population

\begin{tabular}{lrrrrrrrr}
\hline Pop & \multicolumn{1}{l}{$N$} & \multicolumn{1}{l}{$S$} & \multicolumn{1}{l}{ h } & \multicolumn{1}{l}{ Hd } & \multicolumn{1}{l}{$k$} & $\pi \times 10^{3}$ & $A$ & $A_{p r v}$ \\
\hline 1 & 16 & 25 & 14 & 0.92 & 2.85 & 2.43 & 8 & 1 \\
2 & 17 & 28 & 10 & 0.77 & 7.58 & 6.46 & 6 & 0 \\
3 & 15 & 27 & 9 & 0.75 & 7.56 & 6.44 & 6 & 1 \\
4 & 21 & 27 & 8 & 0.84 & 3.90 & 3.33 & 5 & 0 \\
5 & 16 & 20 & 9 & 0.87 & 5.94 & 5.06 & 7 & 0 \\
6 & 15 & 20 & 12 & 0.87 & 2.88 & 2.46 & 9 & 2 \\
7 & 15 & 30 & 13 & 0.86 & 5.90 & 5.03 & 9 & 3 \\
8 & 16 & 30 & 11 & 0.86 & 3.84 & 3.28 & 8 & 0 \\
9 & 16 & 27 & 13 & 0.91 & 4.44 & 3.81 & 8 & 3 \\
10 & 15 & 29 & 11 & 0.90 & 6.64 & 5.66 & 9 & 0 \\
11 & 15 & 24 & 8 & 0.55 & 5.87 & 5.00 & 5 & 0 \\
12 & 10 & 27 & 9 & 0.91 & 10.33 & 8.81 & 6 & 0 \\
13 & 16 & 9 & 8 & 0.64 & 1.27 & 1.09 & 6 & 0 \\
14 & 16 & 29 & 12 & 0.90 & 7.28 & 6.21 & 9 & 1 \\
15 & 23 & 28 & 10 & 0.86 & 7.13 & 6.08 & 7 & 1 \\
16 & 15 & 25 & 9 & 0.80 & 9.42 & 8.03 & 4 & 0 \\
17 & 18 & 33 & 15 & 0.92 & 8.03 & 6.84 & 11 & 2 \\
18 & 18 & 23 & 8 & 0.84 & 5.20 & 4.44 & 6 & 0 \\
19 & 15 & 11 & 7 & 0.77 & 1.96 & 1.68 & 6 & 0 \\
20 & 16 & 20 & 10 & 0.86 & 4.47 & 3.81 & 7 & 2 \\
21 & 15 & 28 & 11 & 0.87 & 8.14 & 6.94 & 9 & 1 \\
22 & 15 & 28 & 11 & 0.77 & 7.00 & 5.97 & 8 & 1 \\
23 & 16 & 33 & 15 & 0.92 & 5.44 & 4.64 & 12 & 3 \\
24 & 16 & 28 & 12 & 0.86 & 3.98 & 3.39 & 9 & 2 \\
25 & 16 & 31 & 11 & 0.86 & 6.12 & 5.23 & 9 & 2 \\
26 & 16 & 30 & 10 & 0.74 & 5.46 & 4.66 & 6 & 0 \\
27 & 16 & 29 & 14 & 0.85 & 5.75 & 4.90 & 10 & 2 \\
28 & 17 & 31 & 15 & 0.87 & 4.84 & 4.13 & 10 & 3 \\
29 & 26 & 29 & 12 & 0.83 & 2.49 & 2.12 & 10 & 2 \\
30 & 10 & 26 & 11 & 0.87 & 4.96 & 4.23 & 8 & 1 \\
\hline $0 t a l$ & 487 & 75 & 109 & 0.89 & 5.77 & 4.92 & 58 & 33 \\
\hline & & & & & & & &
\end{tabular}

Statistical analyses

\section{Variability of TLR2}

TLR2 haplotype reconstruction was performed in DnaSP v 6.11.01 (Rozas et al. 2017) using the PHASE algorithm with default settings of a thinning interval of one, 100 burn-in iterations and 100 main iterations. The obtained sequences were submitted to the GenBank database (see Table S1 for accession numbers). Summary statistics of genetic diversity of the TLR2 gene (number of polymorphic sites $-S$, number of haplotypes $-h$, haplotype diversity $-H d$, nucleotide diversity- $\pi$, average number of nucleotide differences - $k$, and number of amino acid variants $-A$ ), were calculated for each population and for the whole sample set using DnaSP v 6.11.01.

The phylogenetic relationships of all TLR2 sequences were reconstructed using Median Joining network analysis in PopArt v 1.7 (French et al. 2014), and compared with mtDNA lineage frequencies. We conducted a phylogenetic analysis of TLR2 haplotypes using the data obtained in this study. A maximum likelihood phylogenetic tree was constructed in Mega 7.0.26 (Kumar et al. 2016) using 10,000 bootstrap replications, with model $\mathrm{K} 2+\mathrm{G}+\mathrm{I}$ previously indicated as the best-fitting model by Mega 7.0.26 (having the lowest value of Bayesian Information Criterion), using 95 TLR2 sequences from the GenBank database (see Table S2 for accession numbers), and with Myodes rutilus sequence as an outgroup (GenBank accession number: HM215590). These sequences were aligned as previously described and cropped to the same length (1149 bp). Mega 7.0.26 was used to prepare a protein relationship reconstruction. We applied model JTT $+\mathrm{G}+\mathrm{I}$ as the best-fitting model.

We compared the frequencies of different TLR2 clusters $(\mathrm{C} 1, \mathrm{C} 2$ and $\mathrm{C} 3)$ to the frequencies of the two mtDNA lineages (the Carpathian and Eastern; Tarnowska et al. 2016) across the 30 studied populations (frequencies of TLR2 clusters and mtDNA lineages are shown in Table S3), using the rcor.test implemented in the "Ime4" package $R$ (Bates et al. 2015; http://www.R-project.org.).

\section{Environmental data}

Climate data, including mean temperature values, were obtained from the WorldClim database (Hijmans et al. 2005); available online (http://www.worldclim.org). Values of the climate variables for each the studied populations were calculated as the means across all sampling plots occupied by each population. The percentage cover of forest, water, grassland, and urban area were calculated for each of the populations, including a $2-\mathrm{km}$ radius buffer around each area, using ArcGIS 10.2 (Redlands, CA: ESRI 2012) and the CORINE Land Cover 2006 dataset (European Environment Agency, Copenhagen 2007). The number of days with snow 
cover and snow depth were determined based on vectorized maps of mean snow fall in Poland over the period 1970-2000 (Institute of Meteorology and Water Management - National Research Institute, http://www.imgw.pl/en/) for the area occupied by each of these populations.

\section{Factors affecting $B$. afzelii prevalence}

As an initial step in variable selection for generalized linear mixed model (GLMM) analysis, we tested for correlations between a range of genetic, climatic and environmental variables (Table S3), using the rcor.test function of the "Ime4" package in $R$. To avoid correlated variables (Table $\mathrm{S} 5$ ) and to reduce their numbers we ran PCA analysis for climatic and environmental variables to find the subset of those variables, which best explained the observed variation among populations. The optimum PCA result included factors such as forest cover, winter temperature, thickness of snow cover, and snow retention time, which are factors that are known to infect the DIN and therefore the B. afzelii infection risk (Karbowiak 2014; Medlock and Leach 2015). The first two axes of the PCA explained $80.6 \%$ of the variation (Fig. S1). The PC1 reflected winter conditions: mean January temperature, snow depth and mean snow retention time, and the PC2 reflected forest cover.

We identified 7 factors, which potentially could have affected the Borrelia afzelii prevalence among bank voles: (1) TLR2 genotype, (2) mtDNA lineage, (3) age, (4) sex, (5) winter conditions (PC1), (6) forest cover (PC2) and (7) trapping season (Table S4). We did not include the year of sampling, because 24 of the 30 populations were sampled in the same year (2012). We tested these selected factors with results from 393 bank voles, excluding 94 juveniles due to lack of sex identification (none of the excluded individuals were infected with $B$. afzelii).

Infection status ( $0=$ uninfected, $1=$ infected $)$ are binomial data and therefore we used GLMMs with binomial errors to test the impacts of factors which may have affected B. afzelii prevalence among bank vole individuals. GLMMs include both fixed and random effects. We modelled the bank vole population as a random effect (30 populations - number of populations limiting total number of fixed effects in the model to seven variables), and compared GLMMs. We used data concerning the mtDNA lineage (Carpathian or Eastern), sex, and age class (distinguished based on body weight — adults $\geq$ $18 \mathrm{~g}$ and juveniles $<18 \mathrm{~g}$; Pucek 1984). Winter conditions and the forest cover were included in the models as the values of the two first axes of PCA. Information on the timing of trapping was included, using four sampling time periods ( $\mathrm{I}-$ the first half of July, II — the second half of July, III- the second half of August, IV - the first half of September). We did not trap bank voles in June and the first half of August. Information about TLR2 clusters was coded in two ways to compare these approaches. In the first way, we used information about TLR2 cluster genotypes, and in the second way, we used the number of $\mathrm{C} 2$ alleles (which are predicted to reduce susceptibility of $B$. afzelii infection).

We applied an information theoretic approach to model selection, using a second-order correction for small sample size, Akaike's information criterion- $\mathrm{AIC}_{\mathrm{c}}$ (Burnham and Anderson 2002), implemented in the 'MuMIn' $R$ package (Barton 2014). All statistical analyses were completed in $R$ (R Development Core Team 2016).

\section{Results}

\section{Borrelia afzelii infection prevalence in bank voles}

Among 487 analysed samples of bank voles, we detected 59 Borrelia afzelii positive cases, meaning the overall infection prevalence of the study area was $12.1 \%$ (Table 2), which varied at the local level from 0 to $37.5 \%$ between populations (Fig. 2 lower panel and Table S6). The results of a chi-squared test did not show any differences in infection prevalence between 30 studied bank vole populations $\left(\chi^{2}=35.7, \mathrm{df}=29\right.$, $p=0.18$ ). Fifteen of the 59 bank vole samples that tested positive were sequenced for an 89-bp fragment of the $f l a B$ gene of $B$. afzelii. All 15 sequences matched to the reference sequence of B. afzelii (GenBank accession number: MG944963, positions: $400-488 \mathrm{bp}$ ).

\section{MtDNA lineage distribution in NE Poland}

The mtDNA lineage frequencies of studied populations were obtained in a previous study by our research group (Tarnowska et al. 2016). All specimens from the new population investigated in the current study belonged to the Eastern mtDNA lineage (haplotypes H2, H77, H48 and H78), described previously by Tarnowska et al. (2016). In total, 158 (32.4\%) of the 487 individuals belonged to the Carpathian lineage and $329(67.6 \%)$ to the Eastern lineage. We identified three pure Carpathian populations (in the westernmost part of the study area), eight pure Eastern populations (located in the eastern part of the study area) and 19 mixed populations of both lineages (Fig. 1). These two lineages formed a contact zone, which varied in width from $45 \mathrm{~km}$ (southern part of the study area) to $243 \mathrm{~km}$ (in the northern part) (Tarnowska et al. 2016).

\section{Genetic variability of the TLR2 in bank voles}

In total, we obtained 109 haplotypes of TLR2, with 75 polymorphic sites, including 87 haplotypes detected for the first time (see Table S1). Among all identified haplotypes, 76 (70\%) belonged to cluster TLR2 $2_{C 1}, 17(15 \%)$ to TLR2 $2_{C 2}$ 
Table 2 List of the TLR2 genotypes of the bank vole in NE Poland with numbers and percentage frequencies of all individuals and bank voles infected with Borrelia afzelii

\begin{tabular}{|c|c|c|c|c|}
\hline \multirow[t]{2}{*}{ TLR2 genotype } & \multicolumn{2}{|c|}{ All analysed bank voles } & \multicolumn{2}{|c|}{ Bank voles infected with $B$. afzelii } \\
\hline & $N$ & $\%$ & $N$ & $\%$ \\
\hline $\mathrm{C} 1 / \mathrm{C} 1$ & 350 & 71.9 & 42 & 8.6 \\
\hline $\mathrm{C} 2 / \mathrm{C} 2$ & 4 & 0.8 & 1 & 0.2 \\
\hline $\mathrm{C} 3 / \mathrm{C} 3$ & 8 & 1.6 & 1 & 0.2 \\
\hline $\mathrm{C} 1 / \mathrm{C} 2$ & 57 & 11.7 & 6 & 1.2 \\
\hline $\mathrm{C} 1 / \mathrm{C} 3$ & 63 & 12.9 & 9 & 1.9 \\
\hline $\mathrm{C} 2 / \mathrm{C} 3$ & 5 & 1 & 0 & 0 \\
\hline All & 487 & 100 & 59 & 12.1 \\
\hline
\end{tabular}

and $16(15 \%)$ to TLR2 ${ }_{C 3}$. The most frequent haplotype H4.24,

individuals (Fig. S2). Ten of the most frequent haplotypes belonging to cluster TLR2 $2_{C l}$, was found in $26 \%$ of all
Fig. 2 The frequency of the three TLR2 clusters (upper panel) and the infection prevalence of Borrelia afzelii (lower panel) in 30 populations of bank vole in North Eastern Poland

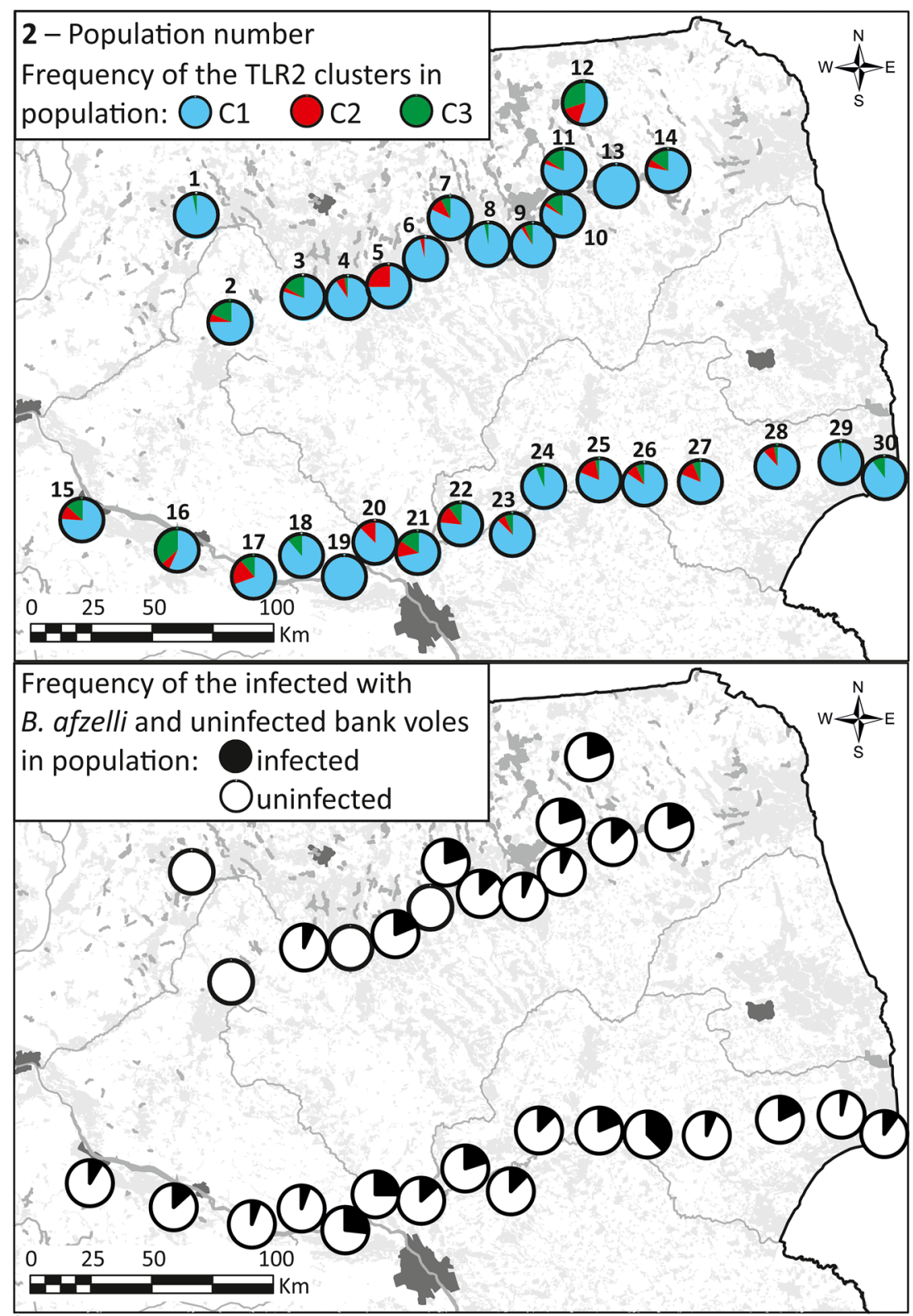


and Eastern mtDNA lineages (Fig. S2). After translation, we obtained 58 amino acid variants (Fig. S4), 41 for cluster TLR $2_{C 1}, 9$ for TLR $2_{C 2}$, and 8 for TLR $2_{C 3}$. The number of amino acid variants ranged from 5 to 12 among populations, while the numbers of private amino acid variants per population varied from 0 to 3 . All considered parameters of genetic variability of the TLR2 gene (number of haplotypes, haplotype and nucleotide diversities and average number of nucleotide differences) were highly diverse among populations (Table 1).

Among the analysed samples (487 individuals and 974 sequences) we identified the TLR2 variants belonging to three clusters (Figs. 2, S2 and S3): TLR2 ${ }_{\mathrm{Cl}}$ was found in $84.2 \%$ of sequences, TLR2 $2_{C 2}$ in $7.2 \%$, and TLR2 ${ }_{C 3}$ in $8.6 \%$. Most of the individuals $(71.9 \%)$ were homozygotes of TLR2 ${ }_{C 1}$. Roughly equal numbers of specimens were heterozygotes of TLR $2_{C 1} /$ TLR2 $_{C 2}(11.7 \%)$ and TLR2 $2_{C 1} /$ TLR $_{C 3}(12.9 \%)$, and only $1 \%$ of individuals were heterozygotes of TLR $2_{C 2} /$ TLR $2_{C 3}$. We also identified homozygotes of TLR2 $2_{C 2}(0.8 \%)$ and TLR2 ${ }_{C 3}(1.6 \%)$. The frequencies of the various TLR2 clusters did not significantly correlate with frequencies of mtDNA lineages in any of the 30 populations studied $\left(r_{\mathrm{s}}\right.$ from -0.35 to $0.35 ; p$ from 0.06 to 0.98 ; Table S5).

\section{Factors influencing $B$. afzelii infection prevalence in bank voles}

Age and sex were indicated as the most important factors determining $B$. afzelii prevalence in bank voles according to the GLMM analysis (Table 3). Adult males were more frequently infected than adult females and juveniles (age: $p<0.001$, sex: $p<0.01)$. AIC-based model selection indicated the negligible importance of environmental factors, TLR2 genotypes or number of TLR2 ${ }_{C 2}$ alleles and distinct mtDNA lineages of bank vole in explaining $B$. afzelii prevalence in voles. The next-best 10 models were within 2 AIC units from the top model (Table 3). All of these models contained age and sex variables indicating that these were the critical explanatory variables. The rest of the explanatory variables in these models were not significant predictors of $B$. afzelii prevalence in bank voles.

\section{Discussion}

\section{Relationships between biological, climatic and environmental variables and $B$. afzelii infection prevalence}

One of the goals of our study was to determine which biological, climatic and environmental variables determined the infection prevalence of B.afzelii in bank voles. We found that B. afzelii infection prevalence was lower in young than in old animals and higher in males than in females. These results are in agreement with previous studies (Tälleklint and Jaenson 1995; Hofmeister et al. 1999; Bunikis et al. 2004). The effect of age could be the result of a longer exposure to ticks and higher activity in older animals than in younger ones (Tälleklint and Jaenson 1995; Tschirren et al. 2013). A further explanation for low infection prevalence in juveniles was provided by Gomez-Chamorro (2019b), who demonstrated that, in a laboratory context, maternally transmitted antibodies may reduce the susceptibility of young bank voles to B.afzelli infection. The described mechanism may effectively limit the propagation of infection among young bank voles. Additionally, due to their higher dispersal rate (Kozakiewicz
Table 3 The averaged confidence set of generalized linear mixed models (GLMMs; $\triangle \mathrm{AIC}_{\mathrm{c}} \leq 2$, confidence set 0.95 ) explaining the spatial distribution of the Borrelia afzelii infection in 393 bank voles from 30 populations in NE Poland. Factors included in models: age, sex, frequency of TLR 2 clusters or number of TLRC2 alleles $(0,1$ or
2), winter conditions, mtDNA lineage, forest cover, sampling season. $K$ the number of estimated parameters, $A I C_{c}$ Akaike's information criterion with a second-order correction for small sample sizes, $\triangle A I C_{c}$ difference in $\mathrm{AIC}_{\mathrm{c}}$ between a given model and the most parsimonious model, $\omega_{i}$ weight of the model

\begin{tabular}{|c|c|c|c|c|c|}
\hline Model & Factors & $K$ & $A I C_{c}$ & $\triangle A I C_{c}$ & $\omega_{i}$ \\
\hline 1 & Age + sex & 4 & 268.99 & 0.00 & 0.10 \\
\hline 2 & Age + sex + number of TLR2 ${ }_{C 2}$ alleles & 5 & 269.39 & 0.41 & 0.08 \\
\hline 3 & Age + sex + winter conditions & 5 & 269.50 & 0.51 & 0.08 \\
\hline 4 & Age + sex + sampling season & 5 & 269.88 & 0.89 & 0.06 \\
\hline 5 & Age + sex + number of TLR $2_{C 2}$ alleles + winter conditions & 6 & 270.20 & 1.21 & 0.05 \\
\hline 6 & Age + sex + number of TLR2 $2_{C 2}$ alleles + sampling season & 6 & 270.34 & 1.36 & 0.05 \\
\hline 7 & Age + sex + forest cover & 5 & 270.43 & 1.44 & 0.05 \\
\hline 8 & Age + sex + mtDNA lineage & 5 & 270.55 & 1.56 & 0.05 \\
\hline 9 & Age + sex + winter conditions + forest cover & 6 & 270.85 & 1.86 & 0.04 \\
\hline 10 & Age + sex + TLR 2 cluster & 5 & 270.90 & 1.91 & 0.04 \\
\hline 11 & Age + sex + number of TLR $2_{C 2}$ alleles + forest cover & 6 & 270.91 & 1.92 & 0.04 \\
\hline
\end{tabular}


et al. 2009), males might acquire more ticks. Perkins et al. (2003) showed that adult males of yellow-necked mouse (Apodemus flavicollis) carried more ticks than other combinations of sex and age class.

In contrast to the results of Tälleklint and Jaenson (1995), we did not detect differences in Borrelia infection prevalence in bank voles captured during different times of the trapping seasons. However, we trapped voles only from July until early September, whereas the highest infection prevalence in bank voles has been observed in autumn (Tälleklint and Jaenson 1995). It is also possible that the $12.1 \%$ infection prevalence revealed in our bank vole populations was too low to track seasonal changes.

In contrast to previous studies (Karbowiak 2014; Medlock et al. 2013; Medlock and Leach 2015), our study did not find any relationship between $B$. affzelii prevalence in the bank vole and either winter conditions or forest cover. We may not have detected such associations, because we used averaged values of climate data representing a time span of 30 50 years, whereas most earlier studies have suggested year-toyear influence on the tick populations (Karbowiak 2014; Medlock et al. 2013; Medlock and Leach 2015). Moreover, any impact of climatic conditions on tick abundance might have been difficult to detect based on weather station data, because ticks could have actively avoided extreme temperatures by seeking microclimate refugia (Kilpatrick et al. 2017). Finally, the study by Hauser et al. (2018) found that climate variables that were measured at the study site were better predictors of tick abundance than climate variables measured at weather stations.

We tested the hypothesis that bank voles representing different clusters and genotypes of TLR2 differ in the prevalence of $B$. afzelii infection. However, we did not find any differences in infection prevalence between adult voles carrying different TLR2 genotypes. The lack of a significant association between infection prevalence in voles and TLR2 genotype frequencies supports the latest findings of GomezChamorro et al. (2019a), whose results stand in opposition to the conclusions of other previously published studies (Tschirren et al. 2013). Under laboratory conditions, GomezChamorro et al. (2019a) did not find any evidence that bank voles carrying different TLR2 genotypes $(\mathrm{C} 1 / \mathrm{C} 1, \mathrm{C} 2 / \mathrm{C} 2, \mathrm{C} 3 /$ $\mathrm{C} 3$ ) varied in susceptibility to $B$. afzelii infection.

It is more likely that the most important factors influencing differences in infection prevalence among voles carrying different TLR2 clusters are the density of infected nymphs and the risk of exposure (Gomez-Chamorro et al. 2019a), these being potentially highly variable even on a small spatial scale (Vourc'h et al. 2016). Other mechanisms which may decrease B. afzelii infection prevalence in bank voles under natural conditions are grooming and acquired resistance to ticks (Dizij and Kurtenbach 1995; Mysterud et al. 2019). In addition, infection with other parasites such as helminth worms may modify the immunological response to bacterial infection in rodents (Hübner et al. 2013). Thus, further studies on the immune genes conferring resistance to pathogens should not only distinguish variation in exposure from variation in susceptibility as indicated by Gomez-Chamorro et al. (2019a), but should also take into account parasite burden in the study organism.

\section{B. afzelii infection detection}

For the majority of bank voles analysed in our study, we used DNA extracted from a fragment of tail to detect infection with B. afzelii. It was possible to detect infection in an animal, when the concentration of bacterial DNA in a sample was at least $2 \times 10^{-4} \mathrm{ng} / \mu \mathrm{l}$. Previous studies have shown differences in spirochete load between tissues and organs of voles: the smallest bacterial loads were observed in the heart and bladder, while the highest were observed in the skin and joints (Gomez-Chamorro et al. 2019a; Zhong et al. 2019). Our study showed that the tip of a tail ( $\sim 4 \mathrm{~mm}$, skin and tail bones) may also be used successfully for detection of $B$. afzelii infection.

\section{Variability of the TLR2 gene and spatial distribution of TLR2 clusters}

One of the aims of this study was to describe the genetic diversity of the TLR2 gene and to detect differences in the frequency of the $\mathrm{TLR}_{C 2}$ cluster in populations of bank voles from NE Poland. Within the study area, over $80 \%$ of analysed sequences belonged to the most common TLR $2_{C 1}$ cluster, while the other two clusters (TLR2 ${ }_{C 2}$ and TLR2 $2_{C 3}$ ) occurred in fewer than $10 \%$ of all analysed specimens. We found a discrepancy in $\mathrm{TLR}_{\mathrm{C} 2}$ cluster frequency between our study and an earlier study by Tschirren (2015). According to the Tschirren study, the frequency of the protective $\mathrm{TLR}_{\mathrm{C} 2}$ cluster in Poland was 29\%, based on 12 individuals. Our results, based on a much larger data set (487 individuals), indicate that the frequency of this cluster is in fact much lower (7.2\%). We found that the distribution of the $\mathrm{TLR}_{\mathrm{C} 2}$ cluster did not have a clear spatial structure, and varied from 0 to $25 \%$ among populations in NE Poland. Therefore, the study of Tschirren (2015) is likely to reflect only the $\mathrm{TLR}_{C 2}$ cluster frequency of one location in Poland.

Of the three TLR2 clusters found in bank vole populations in NE Poland, TLR2 ${ }_{C 3}$ was reported for the first time in this geographic region in the current study. This variant has already been described in Western Europe, with the highest recorded frequency in Spain (Morger et al. 2015). The genetic diversity of the TLR2 gene was high across all studied populations, similar to results obtained by Morger et al. (2015) for Central Europe, and those of Kloch et al. (2018) for two populations from NE Poland. Moreover, the number of private alleles was high, which indicates high population 
differentiation, despite the regional scale of the study. Our results are in concordance with previous research performed by Kloch et al. (2018). We showed that there was no spatial genetic structure of different TLR2 clusters at the regional scale, while Cornetti et al. (2018) showed clear spatial structure of TLR2 clusters, which depended on the risk of $B$. afzelii infection. We observed dominance of the TLR2 ${ }_{C l}$ cluster (in most populations its frequency was over $70 \%$ ) and shifts in the frequency of the other two clusters (from 0 to $36 \%$ ). Analyses performed on a continental scale have shown more distinct spatial patterns of TLR2 clustering (Morger et al. 2015; Tschirren 2015), but it was likely due to low sample size per country $(<20)$.

Correlation tests showed that there was no structuring of TLR2 clusters similar to genetic and spatial structure described for the mtDNA marker. A comparison of TLR2 genetic diversity with the variability of neutral markers in the same study area (10 microsatellite loci, Tarnowska et al. 2019), showed similar values in the mean number of alleles/ population, but not in the number of private alleles, which were higher for TLR2 (from 0 to 3, while the number of private alleles in microsatellite loci per population was from 0 to 0.6 ).

\section{Parasite-mediated selection acting on the TLR2 gene}

Parasite-mediated selection can be an important driver of evolution of the innate immune systems of hosts. Kloch et al. (2018) showed that some variants of the bank voles' TLR2 gene are associated with resistance to Babesia sp., which may reduce the fitness of voles and cause higher mortality, and to Heligmosomus mixitum. Similarly, in field vole (Microtus agrestis) polymorphism within TLR2 gene was associated with resistance to Cestode burden (Turner et al. 2011). Finally, Tschirren et al. (2013) indicated associations of TLR2 haplotypes with variation in susceptibility to $B$. afzelii.

However, in our study, we did not detect any association between TLR2 variability and differences in B. afzelii prevalence among voles, and we concluded that the impact of this pathogen in the studied populations was negligible, but we cannot exclude differences in virulence among $B$. afzelii. On one hand, our findings are supported by previous studies (Moody et al. 1994; Schwanz et al. 2011; Chambert et al. 2012; Voordouw et al. 2015; Cayol et al. 2018). For example, Moody et al. (1994) showed that only infants of the whitefooted mouse (Peromyscus leucopus) suffered from symptoms associated with $B$. burgdorferi infection, such as arthritis, carditis and neurological abnormalities. Capture-mark recapture studies in the field showed that Borrelia does not reduce survival of rodents and sea birds (Chambert et al. 2012; Voordouw et al. 2015). Experimental infections showed that Borrelia infection did not affect the health or behaviour of the white-footed mouse (Schwanz et al. 2011). Voordouw et al. (2015) point out that selection promotes B. burgdorferi genotypes which cause chronic, avirulent infection in their rodent host, because the transmission of bacteria depends on host mobility. On the other hand, B. afzelii infection did not influence bank voles' survival, but it had an impact on the reproductive success and spacing behaviour of bank voles (Cayol et al. 2018).

\section{Different evolutionary history of mtDNA and TLR2 genes}

We did not confirm our hypothesis that frequencies of TLR2 clusters differ between individuals belonging to two different mtDNA lineages of the bank vole in NE Poland. We detected the most common, deepest rooted (early arisen, considered as evolutionary older) haplotypes of TLR2 in both mtDNA lineages (see Fig. S2). Only the rarest haplotypes of TLR2, located at the edges of the TLR2 phylogenetic network (newly arisen) were associated with only one lineage. Similar to results presented by Morger et al. (2015), all three TLR2 clusters detected in North Eastern Poland were identified in bank vole individuals belonging to both the Carpathian and Eastern mtDNA lineages.

Morger et al. (2015) and Tschirren (2015) did not find any relationship between the distribution of the mtDNA lineages and the TLR2 clusters in bank vole populations across Europe. Only one such association between mtDNA has been detected, between the Italian mtDNA lineage of bank vole and the TLR2 ${ }_{C 4}$ (Morger et al. 2015). However, a recent study by Cornetti et al. $(2016,2018)$ showed the presence of the TLR2 ${ }_{C 4}$ cluster within the range of the Western mtDNA lineage of bank voles. Therefore, our study supports the hypothesis of Morger et al. (2015) that TLR2 clusters are evolutionarily older than the divergence of mtDNA phylogenetic lineages in bank voles.

\section{Conclusion}

Question of the role of the TLR2 gene in maintaining immunity to $B$. afzelii is still open. In our study, we did not confirm that the C2 cluster of the TLR2 gene was involved in shaping resistance to $B$. affzelii infection. The mechanism of resistance to $B$. afzelii may be somehow associated with the TLR2 gene, but a deeper analysis of other immune genes, interactions between different parasites co-infecting a host, acquired immunity and behaviour of the host species is now required to reveal the exact role of this gene in immune response to Borrelia infection, as already proposed by Dizij and Kurtenbach (1995) and Mysterud et al. (2019). Our study indicates that $B$. afzelii, at least in NE Poland, is not a predominant driver of parasite-mediated selection in bank vole populations. 
Acknowledgements We thank Drs Tomasz Borowik and Michał Żmihorski for their help with the statistical analyses in $R$ and employees of the National Institute of Public Health (NIZP-PZH, https://www.pzh. gov.pl/) for providing a sample of inactivated Borrelia afzelii. We thank the anonymous reviewers for their helpful comments. This study was financed by the National Science Centre in Poland, project number: UMO-2014/13/N/NZ8/02472 to ET. The sample collection in the year 2006 was financed by the Ministry of Science and Higher Education, project no. 2 P06L 00629 to BJ and in the years 2011-2013 by the Foundation for Polish Science, project number: POMOST/2010-2/11 to MN (Programme Innovative Economy, one of six national programmes under the National Strategy Reference Framework, which was cofinanced from the European Regional Development Fund of the EU).

\section{Compliance with ethical standards}

Conflict of interest The authors declare that they have no conflict of interest.

Ethical approval All procedures in this study involving animals were performed in accordance with the ethical standards of the Local Ethical Commission in Białystok, permissions nos. 07/2004, 15/2006, 16/2011, 43/2011, 12/2013 and 26/2014.

Open Access This article is licensed under a Creative Commons Attribution 4.0 International License, which permits use, sharing, adaptation, distribution and reproduction in any medium or format, as long as you give appropriate credit to the original author(s) and the source, provide a link to the Creative Commons licence, and indicate if changes were made. The images or other third party material in this article are included in the article's Creative Commons licence, unless indicated otherwise in a credit line to the material. If material is not included in the article's Creative Commons licence and your intended use is not permitted by statutory regulation or exceeds the permitted use, you will need to obtain permission directly from the copyright holder. To view a copy of this licence, visit http://creativecommons.org/licenses/by/4.0/.

\section{References}

Bartoń K (2014) MuMIn: multi-model inference. R package, version 1.10.0. Available at: http://cran.r-project.org/web/packages/ MuMIn/MuMIn.pdf

Bates D, Maechler M, Bolker B, Walker S (2015) Fitting linear mixedeffects models using lme4. J Stat Softw 67:1-48. https://doi.org/10. 18637/jss.v067.i01

Bunikis J, Tsao J, Luke CJ, Luna MG, Fish D, Barbour AG (2004) Borrelia burgdorferi infection in a natural population of Peromyscus leucopus mice: a longitudinal study in an area where Lyme borreliosis is highly endemic. J Infect Dis 189:1515-1523. https://doi.org/10.1086/382594

Burnham KP, Anderson DR (2002) Model selection and multi-model inference: a practical information-theoretic approach. Springer, New York

Cayol C, Koskela E, Mappes T, Siukkola A, Kallio ER (2017) Temporal dynamics of the tick Ixodes ricinus in northern Europe: epidemiological implications. Parasites Vectors 10:166. https://doi.org/10. 1186/s13071-017-2112-x

Cayol C, Giermek A, Gomez-Chamorro A, Hytönen J, Kallio ER, Mappes T, Salo J, Voordouw MJ, Koskela E (2018) Borrelia afzelii alters reproductive success in a rodent host. Proc R Soc B 285: 20181056. https://doi.org/10.1098/rspb.2018.1056
Chambert T, Staszewski V, Lobato E, Choquet R, Carrie C, McCoy KD, Tveraa T, Boulinier T (2012) Exposure of black-legged kittiwakes to Lyme disease spirochetes: dynamics of the immune status of adult hosts and effects on their survival. J Anim Ecol 81:986-995. https:// doi.org/10.1111/j.1365-2656.2012.01979.x

Coipan CE, van Duijvendijk GLA, Hofmeester TR, Takumi K, Sprong H (2018) The genetic diversity of Borrelia afzelii is not maintained by the diversity of the rodent hosts. Parasites. Vectors. 11:454. https:// doi.org/10.1186/s13071-018-3006-2

Cornetti L, Lemoine M, Hilfiker D, Morger J, Reeh K, Tschirren B (2016) Higher genetic diversity on mountain tops: the role of historical and contemporary processes in shaping genetic variation in the bank vole. Biol J Linn Soc 118:233-244. https://doi.org/10.1111/ bij. 12723

Cornetti L, Hilfiker D, Lemoine M, Tschirren B (2018) Small-scale spatial variation in infection risk shapes the evolution of a Borrelia resistance gene in wild rodent. Mol Ecol 27:3515-3524. https:// doi.org/10.1111/mec.14812

Deffontaine V, Libois R, Kotlík P, Sommer R, Nieberding C, Paradis E, Searle JB, Michaux JR (2005) Beyond the Mediterranean peninsulas: evidence of central European glacial refugia for a temperate forest mammal species, the bank vole (Clethrionomys glareolus). Mol Ecol 14:1727-1739. https://doi.org/10.1111/j.1365-294X. 2005.02506.x

Diuk-Wasser MA, Hoen AG, Cislo P, Brinkerhoff R, Hamer SA, Rowland M, Cortinas R, Vourc'h G, Melton F, Hickling GJ, Tsao JI, Bunikis J, Barbour AG, Kitron U, Piesman J, Fish D (2012) Human risk of infection with Borrelia burgdorferi, the Lyme disease agent, in Eastern United States. Am J Trop Med Hyg 86:320 327. https://doi.org/10.4269/ajtmh.2012.11-0395

Dizij A, Kurtenbach K (1995) Clethrionomys glareolus, but not Apodemus flavicollis, acquires resistance to Ixodes ricinus $\mathrm{L}$, the main European vector of Borrelia burgdorferi. Parasite Immunol 17:177-183. https://doi.org/10.1111/j.1365-3024.1995.tb00887.x

ESRI (Environmental Systems Resource Institute) (2012) ArcGIS 10.2. [computer program]. ESRI, Redlands

Estrada-Peña A, Cutler S, Potkonjak A, Vassier-Tussaut M, Van Bortel W, Zeller H, Fernandez-Ruiz N, Mihalca AD (2018) An updated meta-analysis of the distribution and prevalence of Borrelia burgdorferi s.1. in ticks in Europe. Int J Health Geogr 17:41. https://doi.org/10.1186/s12942-018-0163-7

Franke J, Hildebrandt A, Dorn W (2013) Exploring gaps in our knowledge on Lyme borreliosis spirochaetes - updates on complex heterogeneity, ecology, and pathogenicity. Ticks Tick Borne Dis 4:1125. https://doi.org/10.1016/j.ttbdis.2012.06.007

French N, Yu S, Biggs P, Holland B, Fearnhead P, Binney B, Fox A, Grove-White D, Leigh JW, Miller W, Muellner P, Carter P (2014) Evolution of Campylobacter species in New Zealand. In: Sheppard SK, Méric G (eds) Campylobacter ecology and evolution. Caister Academic Press, Norfolk, pp 221-240

Garantziotis S, Hollingsworth JW, Zaas AK, Schwartz DA (2008) The effect of Toll-like receptors and Toll-like receptor genetics in human disease. Ann Rev Med 59:343-359. https://doi.org/10.1146/ annurev.med.59.061206.112455

Gomez-Chamorro A, Battilotti F, Cayol C, Mappes T, Koskela E, Boulanger N, Genné D, Sarr A, Voordouw MJ (2019a) Susceptibility to infection with Borrelia afzelii and TLR2 polymorphism in a wild reservoir host. Sci Rep 9:6711. https://doi.org/10. 1038/s41598-019-43160-3

Gomez-Chamorro A, Heinrich V, Sarr A, Roethlisberger O, Genné D, Bregnard C, Jacquet M, Voordouw MJ (2019b) Maternal antibodies provide bank voles with strain-specific protection against infection by the Lyme disease pathogen. Appl Environ Microbiol 85:e1887e01819. https://doi.org/10.1128/AEM.01887-19

Haldane JBS (1949) Disease and evolution. La Ricerca Scientifica 19:68 76 
Hall TA (1999) BioEdit: a user-friendly biological sequence alignment editor and analysis program for Windows 95/98/NT. Nucleic Acids Symp Ser 41:95-98

Hanincová K, Schäfer SM, Etti S, Sewell HS, Taragelová V, Ziak D, Labuda M, Kurtenbach K (2003a) Association of Borrelia afzelii with rodents in Europe. Parasitology 126:11-20. https://doi.org/10. $1017 / \mathrm{s} 0031182002002548$

Hanincová K, Taragelová V, Koci J, Schäfer SM, Hails R, Ullmann AJ, Piesman J, Labuda M, Kurtenbach K (2003b) Association of Borrelia garinii and B. valaisiana with songbirds in Slovakia. Appl Environ Microbiol 69:2825-2830. https://doi.org/10.1128/ AEM.69.5.2825-2830.2003

Hanincová K, Kurtenbach K, Diuk-Wasser M, Brei B, Fish D (2006) Epidemic spread of Lyme borreliosis, Northeastern United States. Emerg Infect Dis 12:604-611. https://doi.org/10.3201/eid1204. 051016

Hauser G, Rais O, Morán Cadenas F, Gonseth Y, Bouzelboudjen M, Gern L (2018) Influence of climatic factors on Ixodes ricinus nymph abundance and phenology over a long-term monthly observation in Switzerland (2000-2014). Parasites Vectors 11:289. https://doi.org/ 10.1186/s13071-018-2876-7

Hijmans RJ, Cameron SE, Parra JL, Jones PG, Jarvis A (2005) Very high resolution interpolated climate surfaces for global land areas. Int $\mathrm{J}$ Climatol 25:1965-1978. https://doi.org/10.1002/joc.1276

Hirschfeld M, Kirschning CJ, Schwandner R, Wesche H, Weis JH, Wooten RM, Weis JJ (1999) Cutting edge: inflammatory signaling by Borrelia burgdorferi lipoproteins is mediated by toll-like receptor 2. J Immunol 163:2382-2386

Hofmeester TR, Coipan EC, Van Wieren SE, Prins HHT, Takken W, Sprong H (2016) Few vertebrate species dominate the Borrelia burgdorferi s.1. life cycle. Environ Res Lett 11:043001. https://doi. org/10.1088/1748-9326/11/4/043001

Hofmeister EK, Ellis BA, Glass GE, Childs JE (1999) Longitudinal study of infection with Borrelia burgdorferi in a population of Peromyscus leucopus at a Lyme disease-enzootic site in Maryland. Am J of Trop Med Hyg 60:598-609. https://doi.org/10.4269/ajtmh. 1999.60 .598

Hübner MP, Layland LE, Hoerauf A (2013) Helminths and their implication in sepsis - a new branch of their immunomodulatory behaviour? Pathog Dis 69:127-141. https://doi.org/10.1111/2049-632X. 12080

Humair PF, Rais O, Gern L (1999) Transmission of Borrelia afzelii from Apodemus mice and Clethrionomys voles to Ixodes ricinus ticks: differential transmission pattern and overwintering maintenance. Parasitology 118:33-42. https://doi.org/10.1017/ s0031182098003564

Institute of Meteorology and Water Management - National Research Institute, IMGW-PIB, http://www.imgw.pl/en/

Karbowiak G (2014) The occurrence of the Dermacentor reticulatus tick - its expansion to new areas and possible causes. Ann Parasitol 60: $37-47$

Kilpatrick AM, Dobson ADM, Levi T, Salkeld DJ, Swei A, Ginsberg HS, Kjemtrup A, Padgett KA, Jensen PM, Fish D, Ogden NH, DiukWasser MA (2017) Lyme disease ecology in a changing world: consensus, uncertainty and critical gaps for improving control. Phil Trans R Soc B 372:20160117. https://doi.org/10.1098/rstb.2016. 0117

Kloch A, Wenzel MA, Laetsch DR, Michalski O, Welc-Falęciak R, Piertney AP (2018) Signatures of balancing selection in toll-like receptor (TLRs) genes - novel insights from a free-living rodent. Sci Rep 8:8361. https://doi.org/10.1038/s41598-018-26672-2

Kotlík P, Deffontaine V, Mascheretti S, Zima J, Michaux JR, Searle JB (2006) A northern glacial refugium for bank voles (Clethrionomys glareolus). Proc Natl Acad Sci U S A 103:14860-14864. https://doi. org/10.1073/pnas.0603237103
Kozakiewicz M, Gortat T, Panagiotopoulou H, GryczyńskaSiemiątkowska A, Rutkowski R, Kozakiewicz A, Abramowicz K (2009) The spatial genetic structure of bank vole (Myodes glareolus) and yellow-necked mouse (Apodemus flavicollis) populations: the effect of distance and habitat barriers. Anim Biol 59:169-187

Kumar S, Stecher G, Tamura K (2016) MEGA7: molecular evolutionary genetics analysis version 7.0 for bigger datasets. Mol Biol Evol 33: 1870-1874. https://doi.org/10.1093/molbev/msw054

Kurtenbach K, Kampen H, Dizij A, Arndt S, Seitz HM, Schaible UE, Simon MM (1995) Infestation of rodents with larval Ixodes ricinus (Acari, Ixodidae) is an important factor in the transmission cycle of Borrelia burgdorferi sl in German woodlands. J Med Entomol 32: 807-817. https://doi.org/10.1093/jmedent/32.6.807

Kurtenbach K, De Michelis S, Etti S, Schafer AM, Sewell HS, Brade V, Kraiczy P (2002) Host association of Borrelia burgdorferi sensu lato - the key role of host complement. Trends Microbiol 10:74 79. https://doi.org/10.1016/s0966-842x(01)02298-3

Medlock JM, Leach SA (2015) Effect of climate change on vector-borne disease risk in the UK. Lancet Infect Dis 15:721-730. https://doi. org/10.1016/S1473-3099(15)70091-5

Medlock JM, Hansford KM, Bormane A, Derdakova M, Estrada-Peña A, George JC, Golovljova I, Jaenson TGT, Jensen JK, Jensen PM, Kazimirova M, Oteo JA, Papa A, Pfister K, Plantard O, Randolph SE, Rizzoli A, Santos-Silva MM, Sprong H, Vial L, Hendrickx G, Zeller H, Van Bortel W (2013) Driving forces for changes in geographical distribution of Ixodes ricinus ticks in Europe. Parasites Vectors 6:1. https://doi.org/10.1186/1756-3305-6-1

Medzhitov R (2001) Toll-like receptors and innate immunity. Nat Rev Immunol 1:135-145. https://doi.org/10.1038/35100529

Moody KD, Terwilliger GA, Hansen GM, Barthold SW (1994) Experimental Borrelia burgdorferi infection in Peromyscus leucopus. J Wild Dis 30:155-161. https://doi.org/10.7589/00903558-30.2.155

Morger J, Råberg L, Hille SM, Helsen S, Štefka J, Al-Sabi MM, Kapel CMO, Mappes T, Essbauer S, Ulrich RG, Bartolommei P, Mortelliti A, Balčiauskas L, van den Brink NW, Rémy A, Bajer A, Cheprakov M, Korva M, García-Pérez AL, Biek R, Withenshaw S, Tschirren B (2015) Distinct haplotype structure at the innate immune receptor toll-like receptor 2 across bank vole populations and lineages in Europe. Biol J Linn Soc 116:124-133. https://doi.org/10.1111/bij. 12593

Mysterud A, Stigum VM, Linløkken H, Herland A, Viljugrein H (2019) How general are generalist parasites? The small mammal part of the Lyme disease transmission cycle in two ecosystems in northern Europe. Oecologia 190:115-126. https://doi.org/10.1007/s00442019-04411-2

Niedziałkowska M, Kończak J, Czarnomska S, Jędrzejewska B (2010) Species diversity and abundance of small mammals in relation to forest productivity in northeast Poland. Ecoscience 17:109-119. https://doi.org/10.2980/17-1-3310

Ostfeld RS, Canham CD, Oggenfuss K, Winchcombe RJ, Keesing F (2006) Climate, deer, rodents, and acorns as determinants of variation in Lyme-disease risk. PLoS Biol 4:1058-1068. https://doi.org/ 10.1371/journal.pbio.0040145

Perez G, Bastian S, Agoulon A, Bouju A, Durand A, Faille F, Lebert I, Rantier Y, Plantard O, Butet A (2016) Effect of landscape features on the relationship between Ixodes ricinus ticks and their small mammal hosts. Parasites Vectors 9:20. https://doi.org/10.1186/ s13071-016-1296-9

Perkins SE, Cattadori IM, Tagliapietra V, Rizzoli AP, Hudson PJ (2003) Empirical evidence for key hosts in persistence of a tick-borne disease. Int J Parasitol 33:909-917. https://doi.org/10.1016/S00207519(03)00128-0

Piesman J, Gern L (2004) Lyme borreliosis in Europe and North America. Parasitology 129:191-220. https://doi.org/10.1017/ S0031182003004694 
Pucek Z (ed) (1984) Klucz do oznaczania ssaków Polski. Państwowe Wydawnictwo Naukowe, Warszawa [in Polish]

R Development Core Team (2016) R: a language and environment for statistical computing. R Foundation for Statistical Computing, Vienna http://www.R-project.org

Råberg L (2012) Infection intensity and infectivity of the tick-borne pathogen Borrelia afzelii. J Evol Biol 25:1448-1453. https://doi.org/10. 1111/j.1420-9101.2012.02515.x

Rozas J, Ferrer-Mata A, Sánchez-DelBarrio JC, Guirao-Rico S, Librado P, Ramos-Onsins SE, Sánchez-Gracia A (2017) DnaSP 6: DNA sequence polymorphism analysis of large datasets. Mol Biol Evol 34:3299-3302. https://doi.org/10.1093/molbev/msx248

Schwanz LE, Voordouw MJ, Brisson D, Ostfeld RS (2011) Borrelia burgdorferi has minimal impact on the Lyme disease reservoir host Peromyscus leucopus. Vector Borne Zoonotic Dis 11:117-124. https://doi.org/10.1089/vbz.2009.0215

Starkel L (ed) (1991) Geografia Polski - środowisko przyrodnicze. Państwowe Wydawnictwo Naukowe, Warszawa [in Polish]

Stojak J, Tarnowska E (2019) Polish suture zone as the goblet of truth in post-glacial history of mammals in Europe. Mammal Res 64:463475. https://doi.org/10.1007/s13364-019-00433-6

Strnad M, Hönig V, Růžek D, Grubhoffer L, Rego ROM (2017) Europewide meta-analysis of Borrelia burgdorferi sensu lato prevalence in questing Ixodes ricinus ticks. Appl Environ Microbiol 83:e0609e00617. https://doi.org/10.1128/AEM.00609-17

Sytykiewicz H, Karbowiak G, Werszko J, Czerniewicz P, Sprawka I, Mitrus J (2012) Molecular screening for Bartonella henselae and Borrelia burgdorferi sensu lato co-existence within Ixodes ricinus populations in central and eastern parts of Poland. Ann Agric Environ Med 19:451-456

Tälleklint L, Jaenson TGT (1995) Is the small mammal (Clethrionomys glareolus) or the tick vector (Ixodes ricinus) the primary overwintering reservoir for the Lyme borreliosis spirochete in Sweden? J Wildl Dis 31:537-540. https://doi.org/10.7589/00903558-31.4.537

Tälleklint L, Jaenson TGT, Mather TN (1993) Seasonal variation in the capacity of the bank vole to infect larval ticks (Acari: Ixodidae) with the Lyme disease spirochete, Borrelia burgdorferi. J Med Entomol 30:812-815. https://doi.org/10.1093/jmedent/30.4.812

Tarnowska E, Niedziałkowska M, Gerc J, Korbut Z, Górny M, Jędrzejewska B (2016) Spatial distribution of the Carpathian and eastern mtDNA lineages of the bank vole in their contact zone relates to environmental conditions. Biol J Linn Soc 119:732-744. https://doi.org/10.1111/bij.12764

Tarnowska E, Niedziałkowska M, Jędrzejewska B (2019) Genetic structure of bank vole population in the contact zone of two lineages in north-eastern Poland. Mammal Biol 96:93-101. https://doi.org/10. 1016/j.mambio.2018.10.011
Tschirren B (2015) Borrelia burgdorferi sensu lato infection pressure shapes innate immune gene evolution in natural rodent populations across Europe. Biol Lett 11:20150263. https://doi.org/10.1098/rsbl. 2015.0263

Tschirren B, Råberg L, Westerdahl H (2011) Signatures of selection acting on the innate immune gene toll-like receptor 2 (TLR2) during the evolutionary history of rodents. J Evol Biol 24:1232-1240. https://doi.org/10.1111/j.1420-9101.2011.02254.x

Tschirren B, Andersson M, Scherman K, Westerdahl H, Råberg L (2012) Contrasting patterns of diversity and population differentiation at the innate immunity gene Toll-like receptor 2 (TLR2) in two sympatric rodent species. Evolution 66:720-731. https://doi.org/10.1111/j. 1558-5646.2011.01473.x

Tschirren B, Andersson M, Scherman K, Westerdahl H, Mittl RRE, Råberg L (2013) Polymorphisms at the innate immune receptor TLR2 are associated with Borrelia infection in a wild rodent population. Proc R Soc Lond B Biol Sci 280:20130364. https://doi.org/ 10.1098/rspb.2013.0364

Turner AK, Begon M, Jackson JA, Bradely JE, Paterson S (2011) Genetic diversity in cytokines associated with immune variation and resistance to multiple pathogens in a natural rodent population. PLoS Genet 7:e1002343. https://doi.org/10.1371/journal.pgen.1002343

van Duijvendijk G, Sprong H, Takken W (2015) Multi-trophic interactions driving the transmission cycle of Borrelia afzelii between Ixodes ricinus and rodents: a review. Parasites Vectors 8:1-11. https://doi.org/10.1186/s13071-015-1257-8

Voordouw MJ, Lachish S, Dolan MC (2015) The Lyme disease pathogen has no effect on the survival of its rodent reservoir host. PLoS One 10:e0118265. https://doi.org/10.1371/journal.pone.0118265

Vourc'h G, Abrial D, Bord S, Jacquot M, Masséglia S, Poux V, Pisanu B, Bailly X, Chapuis JL (2016) Mapping human risk of infection with Borrelia burgdorferi sensu lato, the agent of Lyme borreliosis, in a periurban forest in France. Ticks Tick Borne Dis 7:644-652. https:// doi.org/10.1016/j.ttbdis.2016.02.008

Wooten RM, Ma Y, Yoder RA, Brown JP, Weis JH, Zachary JF, Kirschning CJ, Weis JJ (2002) Toll-like receptor 2 is required for innate, but not acquired, host defense to Borrelia burgdorferi. J Immunol 168:348-355. https://doi.org/10.4049/jimmunol.168.1. 348

Zhong X, Nouri M, Raberg L (2019) Colonization and pathology of Borrelia afzelii in its natural hosts. Ticks Tick-borne Dis 10:822827. https://doi.org/10.1016/j.ttbdis.2019.03.017

Zielony R, Kliczkowska A (2012) Regionalizacja przyrodniczo-leśna Polski 2010. Centrum Informacyjne Lasów Państwowych, Warszawa [in Polish]

Publisher's note Springer Nature remains neutral with regard to jurisdictional claims in published maps and institutional affiliations. 